\title{
Maria Teresa Giaveri, Pour un double circuit des biens symboliques
}

\section{Cecilia Torelli}

\section{Q OpenEdition}

1 Journals

\section{Edizione digitale}

URL: http://journals.openedition.org/studifrancesi/30617

DOI: 10.4000/studifrancesi.30617

ISSN: 2421-5856

\section{Editore}

Rosenberg \& Sellier

\section{Edizione cartacea}

Data di pubblicazione: 1 avril 2006

Paginazione: 184

ISSN: 0039-2944

\section{Notizia bibliografica digitale}

Cecilia Torelli, «Maria Teresa Giaveri, Pour un double circuit des biens symboliques», Studi Francesi

[Online], 148 (XLX | I) | 2006, online dal 30 novembre 2015, consultato il 19 avril 2021. URL: http:// journals.openedition.org/studifrancesi/30617 ; DOI: https://doi.org/10.4000/studifrancesi.30617

Questo documento è stato generato automaticamente il 19 avril 2021.

\section{(c) (i) (9)}

Studi Francesi è distribuita con Licenza Creative Commons Attribuzione - Non commerciale - Non opere derivate 4.0 Internazionale. 


\title{
Maria Teresa Giaveri, Pour un double circuit des biens symboliques
}

\author{
Cecilia Torelli
}

NOTIZIA

MARIA TERESA GIAVERI, Pour un double circuit des biens symboliques, « Recherches \&

Travaux », Poésie et journalisme au XIX ${ }^{\mathrm{e}}$ siècle en France et en Italie, n. 65, 2004, pp. 111-123.

1 L'A. prende spunto dall'episodio del duello avvenuto il 22 luglio 1836 tra Emile de Girardin, direttore de "La Presse", e Armand Carrel, giornalista repubblicano, per introdurre un'analisi dei nuovi rapporti tra stampa, letteratura e società che si vanno formando nella seconda metà del XIX secolo. Baudelaire, Flaubert e Valery sono citati dall'A. a testimonianza del diverso rapporto che si instaura tra l'artista e il suo pubblico: alimentata dalla situazione politica, sociale e economica del tempo, la scrittura diventa un processo di produzione sottomesso alle leggi del mercato, ovvero alla vasta folla anonima dei lettori dei giornali. 